\title{
Renovation of the first sable reserve of Russian empire in the planned Sayanian biosphere reserve
}

\author{
Dmitry Astanin 1,* \\ ${ }^{1}$ Cherepovets State University, Lunacharskogo pr., 5, Cherepovets, 162600, Russian Federation
}

\begin{abstract}
In 1918-1919 Sayanian reserve ceased to exist, even before it officially formalized at the governmental level. Sayanian reserve was reestablished in 1939. But in 1951, the reserve was closed due to lack of security. The existing and planned for opening specially protected areas in the central part of the Eastern Sayans, as well as the Sayan Geopark and the territory of traditional nature use Tofalar would restore the Sayan Reserve to the original borders as a complex of territories with different conservation status. It would be historical justice.
\end{abstract}

\section{Introduction and purpose}

In 1914-1916 took place the great Sayan expedition to study the sable trade under the command of zoologist and hunting expert D.K. Solovyov. The participants of this expedition made many extremely interesting routes in the central, most inaccessible part of Sayan - along the sources of the rivers Kazyr, Kizir, Kan.

At the beginning of the 20th century in Russia there was a sharp decline in the sable population. The tsarist government decided to "recognize for the preservation of sable the urgency of identifying protected areas, so-called reserves." The Barguzinsky district was chosen to organize such reserves as the habitat of the most valuable sable; Minusinsk, Kansky and Nizhneudinsky districts of the Yenisei province ": as areas where sable trade is of the greatest importance for the local population. As a result, in 1915, by the decree of the Irkutsk Governor-General, the territory projected for the Sayan Reserve was removed from hunting territory. After the expedition's work ended at a meeting held on February 25, 1916 under the Department of Agriculture, the proposal to organize the Sayan Sable Reserve in the Yenisei Governorate was approved. The Sayan Reserve began operating a year earlier than Barguzinsky one. The area soon fell into the zone of civil war. In the 1918-1919-ies Sayan Reserve has ceased to exist, not even having time to formalize itself at the government level. The main territory of the reserve was within the Nizhneudinsky district of the Irkutsk region and included a powerful mountain site located in the east of the Kuraginsky district of the Krasnoyarsk Territory.

\footnotetext{
${ }^{*}$ Corresponding author: montenegro.astanin@,mail.ru
} 
An important argument for the reserve was the remoteness of this territory, the absence of a permanent population here. The surprising pictorial of this part of Eastern Sayans and the presence remarkable mountain lakes (Agulskoe, Medvezhie (Bear) et al.) attracted.

"Reserve Nature extremely diverse - rocky peaks of the mountains, various white mountains of a tundra nature, placers of rubble, luxury alpine meadow thickets shrub birch, willow, fir stanza, mighty cedar taiga, .. rivers with rapids and waterfalls, lakes, of which the greatest reaches 12 versts (A verst (Russian: верста, versta) is an obsolete Russian unit of length; equal to 1.0668 kilometres / 0.6629 miles/ 3,500 feet) in length, mineral springs, cascades - and all this in infinitely picturesque combinations draws attention, both of naturalist and of tourist. "- wrote the head of the Sayan expedition D.K. Solovyov. On three sides, there were operational hunting areas adjacent to the reserve, in the east there was a Karagas territory - a foreign reserve. The use of the reserve for tourism purposes was suggested as early as the beginning of the 20th century by D.K. Solovyov. He spoke about the possibility of developing commercial foreign hunting tourism: "A hunter-tourist who is not afraid of hardships paves the way for ordinary tourists, and the importance of developing tourism is most clearly seen in example of Switzerland. Our beautiful and interesting places have all the possibilities to attract tourists".

\section{Historical justification}

The Sayan Reserve was again recreated in 1939. The management of the reserve was located in the tract Summer Agul, which could be reached from Kansk. But in 1951, the reserve was closed due to lack of protection. In the same year, the Altai, Kronotsky, Bashkir and other taiga reserves were liquidated. At the same time, the above-listed reserves have so far been restored as reserves or national parks and have acquired international status as biosphere reserves or are included in the UNESCO World Heritage List. The restoration of the Sayan Reserve can take the way of the Bashkir Reserve, which now has the status of a biosphere reserve formed by a whole complex of protected areas. 


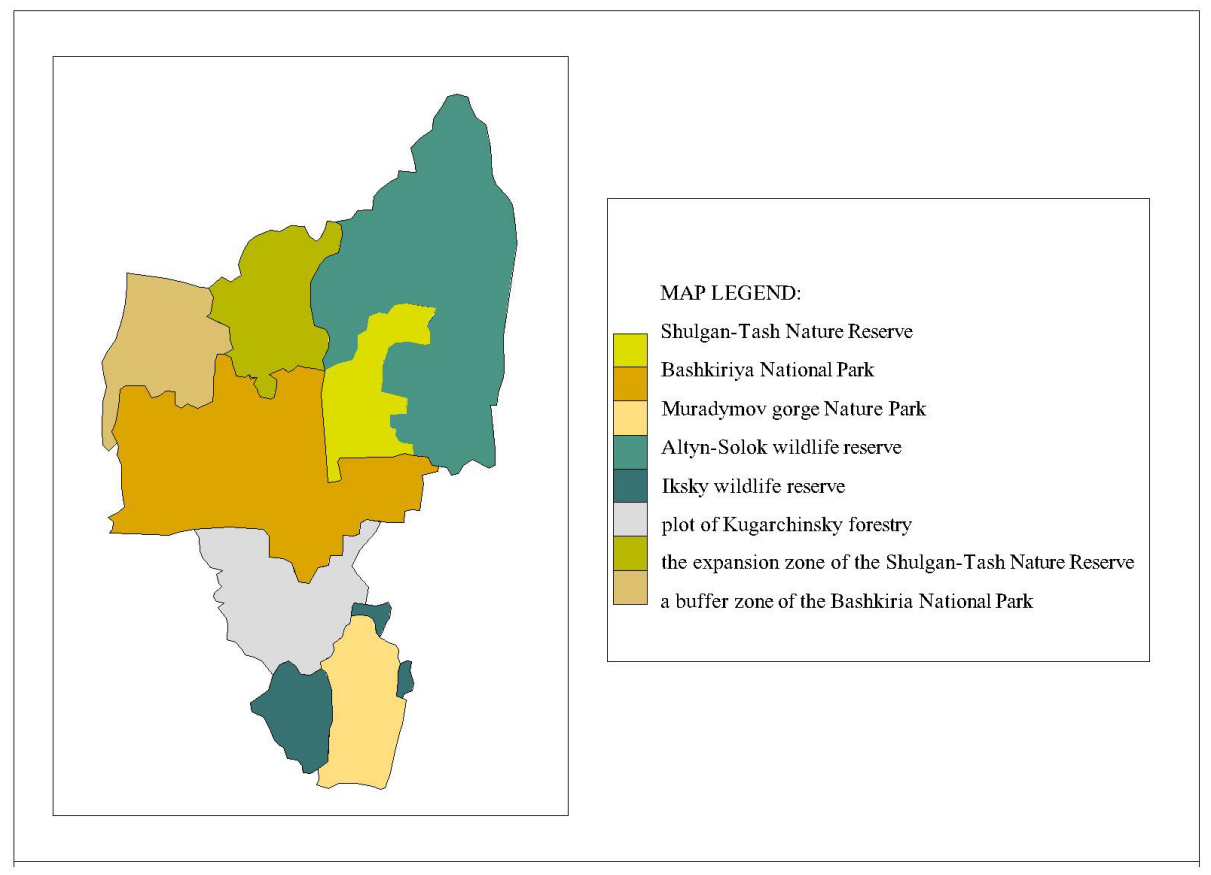

Fig. 1. Map-scheme of natural areas that are part of the Bashkir biosphere reserve

Writer G. A. Fedoseev was also surveyor, geodesist, author of popular books. In 1965, he wrote a very vivid article in Izvestia in defense of the mountain nature of the Sayans. Glavokhota RSFSR (Central Research Laboratory of Hunting and Nature Reserves of the Russian Federation) was ordered to "take measures": first established a local reserve Tofalarsky, and in August 1971 they made it republican (RSFSR, i.e. federal), covering an area of 132.7 thousand hectares (Sayan reserve occupied 1200 thousand hectares, almost 10 times more, it was one of the largest in the USSR). Now, on the border with the Tofalarsky natural state reserve, the Taybinsky reserve has been created and are planning to create a natural park Kanskoye Belogorye and Agulsky complex natural reserve. But, all together they are smaller than the Sayan Reserve. Therefore, in the south and east of the territory of the Sayan Reserve it is possible to create new protected areas: geo-and ethno-parks. 


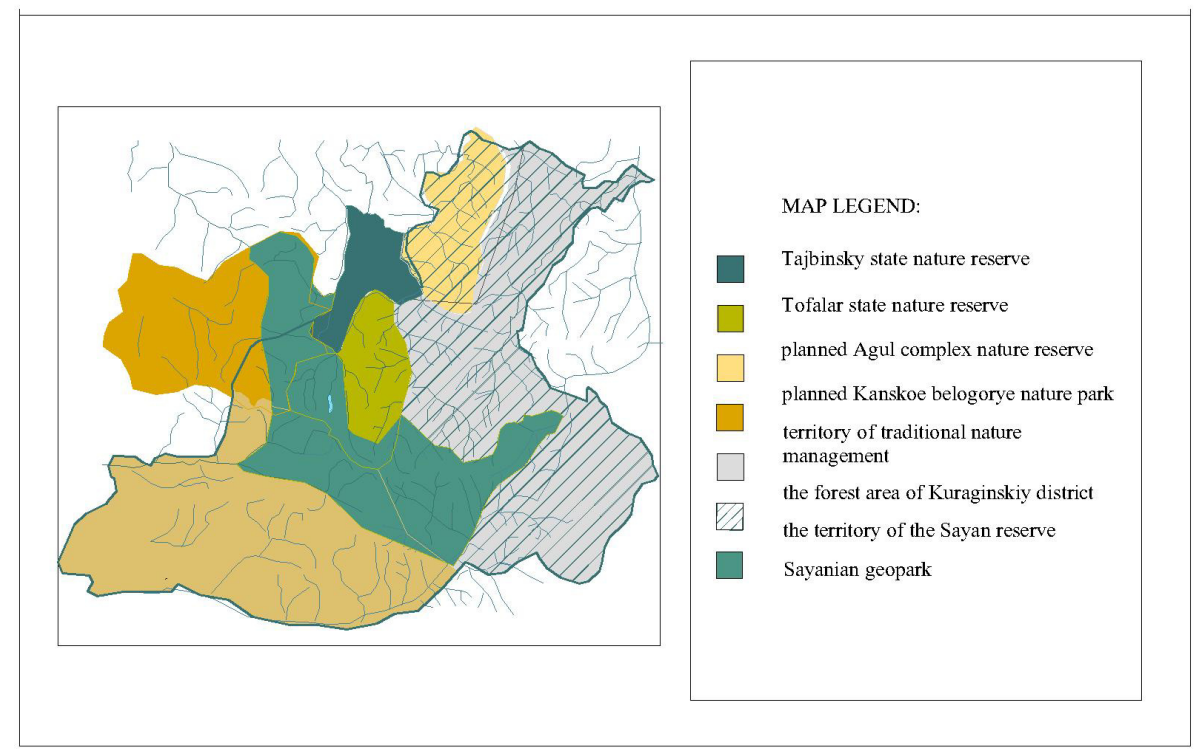

Fig. 2. Map-scheme of natural territories, included in the biosphere reserve, designed in the Central part of Eastern Sayan

In 1938, G. A. Fedoseev, descending from the Kinzeluk range, saw that from a large lake located in the circus of the two-headed peak crowning the spurs of Agul Belkov, a huge waterfall flies from an almost sheer cliff to the Kinzeluk river bed. The height of the cascade is about $330 \mathrm{~m}$. Kinzeluk waterfall is one of the 2 highest waterfalls in Russia. The surrounding area is a very unusual and picturesque place. In the Kinzelyuk valley there are a lot of mineral hydrogen sulphide and narzan type sources. Gas emissions are clearly visible. Now it is the territory of the planned landscape monument of nature of geomorphological value - Kinzeluk waterfall. It is located in the southern part of the territory where the Sayan Reserve was located, and can become the center of education of the Sayan Geopark. Geopark is a tourist and recreational zone, where geological heritage sites are part of a unified concept of conservation, education and sustainable development of the territory, where there is a connection between geological diversity, biodiversity and culture. Geoparks are formed for practical demonstration of the processes of geological development of the Earth. Geopark is a territory with conditionally designated boundaries, which is not a specially protected natural area, but may include fully or partially such areas [1-37].

\section{Geographical justification}

Billions of years ago on the site of the Eastern Sayans was the ocean. In the fractures of the rocks often found fossilized ancient algae. Approximately 15 million years ago the general rise of the Sayans began and their isolation as an independent system. At the latitude of 52$54^{*}$, a powerful glaciation center was formed. Glaciers formed valleys, departing from the 
main mountain range. 300-400 thousand years ago, the water washed out the gorges, which dismembered the massif into a complex system of ridges and spurs. Therefore, the relief of Eastern Sayan has inherent expressive traces of glacial morphosculpture, indicating the significant size of the Quaternary glaciation: pyramidal peaks, punes, circuses, troughs, Carling, glacial lakes, of course, moraine ridges. Numerous glaciers, waterfalls and canyons are of great interest. The task of the Sayan geopark should be a demonstration of the variety of relief forms of glacial origin, which are located within walking distance from the Kinzeluk waterfall:

- the highest peak of Kansky Belogoriya, Pyramid Mountain and the Ilyin Glacier lying on its slopes. Under the Ilyin Glacier there is a small lake, from which the Ilyin Creek originates, falling in cascades into the Maly Agul River. The valley of the river is a glacial trough (planned park Kanskoye Belogorye);

- located between the Small and Large Agul and Kinzeluka rivers, the Orzogai group of loaches with snow-white marble mountains and a nature monument by the Kusurgashev glacier (Tofalarsky zakaznik);

- located on the northeastern slope of the Edelstein Peak, the Stalnov Glacier, which gives rise to the Belaya River, which flows into Kizir $6 \mathrm{~km}$ above Kinzeluk;

- The highest point of the Krasnoyarsk Territory - Grandiose Peak (2922 m) with a cascade of waterfalls on the Vodopadniy creek flowing from the western circus peak, with a total fall height of about $200 \mathrm{~m}$ and a width of at least $1 \mathrm{~m}$;

- the upper reaches of the Vankina River, striking with a combination of bizarre-shaped rocks;

- numerous lakes of glacial origin: the crust and moreno-dammed lakes, including the Agulsky lake, which lies in a tectonic depression (Tofalar reserve);

- giant canyons of the Derbinsky series, for example, Boykishtinsky - $30 \mathrm{~m}$ deep and 8 m wide. A bridge called the Devil was thrown by Fedoseyev;

- The highest peak of Kansky Belogoriya - Pyramid Mountain and the Ilyina Glacier lying on its slopes. Under the Ilyin Glacier there is a small lake, from which originates the Ilyin Stream, falling in cascades into the Small Agul River. The valley of the river is a glacial trough (the planned park Kanskoye Belogorye).

In addition, there are preserved geological monuments of the oldest rocks with a radiological age of about 3.3 billion years, a rudimentary rift zone, including a unique Agul lake. In this territory, in the segments of paleorift structures, modern tectonic activity is manifested and outcrops of thermal sources of weak mineralization, which have not yet been studied.

In the northern spurs of Kansky Belogoriya placer gold deposits, discovered in 1834, are known. The fields were developed in the second half of the XIX - the first half of the XX centuries (the Karagan, Malmyn, Tuksha, Negoda, Sukhoi Log, Yang mines in the Cana valley, Voskresensky and Negote in the Small Agul valley). In the 19th century, local residents worked in gold mines.

Within the northern spurs of the Idar and Tukshinsky belarium, large deposits of copper-nickel ores are known (the Kingashsky ore cluster, which includes the Kingashskoye and Verkhnekingashskoye deposits). Many breeds in the study area are characterized by a higher content of potassium, thorium, uranium, lithium, rubidium, cesium, tantalum, niobium, which explains the biogeochemical characteristics of medicinal plants and animal organs of Eastern Sayan mountains, surpassing analogues from other regions in useful qualities. Numerous mineral springs form natural salt licks, which are actively visited by representatives of the local fauna. Geomorphologic, geobotanical, biogeochemical, and other unique features of the territory favor the creation of youngsters 
for the conservation, reproduction, and selection of red deer and tofalar deer. The development of reindeer husbandry is recognized as a promising direction, capable of providing an increase in the standard of living of the Tofalars and the tourist attractiveness of the territory. The presence of natural resources, a reserve of an unoccupied able-bodied, knowledgeable territory-specific, population creates the prerequisites for building a new viable economic organism.

Tofalaria and adjacent regions served as a testing ground for the development of fundamental geological concepts and theories:

- concept of ancient crown of Asia (E.Syuss, V.Obruchev, etc.);

- concept folded waves E. Arogon;

- concept of tectonic terranes by A.A. Massakovsky;

- concept of the epicratic proterozoid by E.N. Altukhova, etc.

57 books on travel, ethnography of the studied area were written; such authors as V. Chivilikhin, G. Fedoseev and others.

From the end of the 50s, groups of pioneers appeared in the center of the Sayan Mountains.

The first tourist group from Grandiose Peak went north to Cana. And now amateur groups of tourists along the Agul and Gutara, Idar and Kan white mountains reach Gutarsky and Kinzelyuk waterfalls, the Stalnoi (Steel) and Kusurgashev glaciers, the Agulsky and Medvezhy lakes, the Orzagai marble mountains, the Grandiose and Triangulators peaks. Thus, the development of "amateur" and sports tourism determines the significant social potential of geo-and ecotourism.

\section{Conclusion}

Since 2002, there has been a special UNESCO program to support the creation of a worldwide network of national geoparks. Currently, there are 111 geoparks from 32 countries [10-32]. In Russia, on December 31, 2015, only one Altai geopark was created, which demonstrates geological structures, waters, glaciers, glacial relief, paleontology, and processes in the areas of permafrost.

For historical and social reasons, the primordial territory of the Sayan Reserve was sharply reduced to the territory of the Tofalarsky zakaznik, endemic landscapes and indigenous people were outside the protection of the state. Therefore, it is necessary to return to the proposal of D.K. Solovyov, who envisaged the creation in the east of a nonindigenous reserve of the indigenous people of the Central Sayan Tofalars (Karagassky territory). Creating a territory of traditional nature management to the east of the Tofalar reserve will allow preserving the natural landscapes of the highland taiga, ensuring the preservation of traditional nature management and the traditional way of life of the indigenous population - Tofalars.

On the territory of the Krasnoyarsk region there is a traditional territory Popigai, located in the south-eastern part of the territory under the jurisdiction of the municipality of Hantai district. Within the framework of the territory of traditional nature use, any economic and other activity that entails a violation of the security of the territory as a specially protected object of traditional settlement and environmental management of the indigenous and local population is prohibited. Ethno-geo-ecological tourism is the most acceptable form of nature management of the Tofalar-Tugul natural ethnographic region, which allows to realize the principle of sustainable development of the natural environment and cultural heritage of a small ethnos on a limited territory. The development of ethnolandscape tourism in Tofalaria does not require the construction of new hotels in the protected area, although certain improvements to existing cordons and haunts will certainly 
be useful. The indisputable advantage of ethno-ecological tourism and the inclusion of territories of settlements in the ethnographic park is that it can become an effective means of environmental education of the population, an additional source of financial support for the activities of specially protected natural territories and local settlements, to promote the establishment of scientific, educational and cultural ties with other territories.

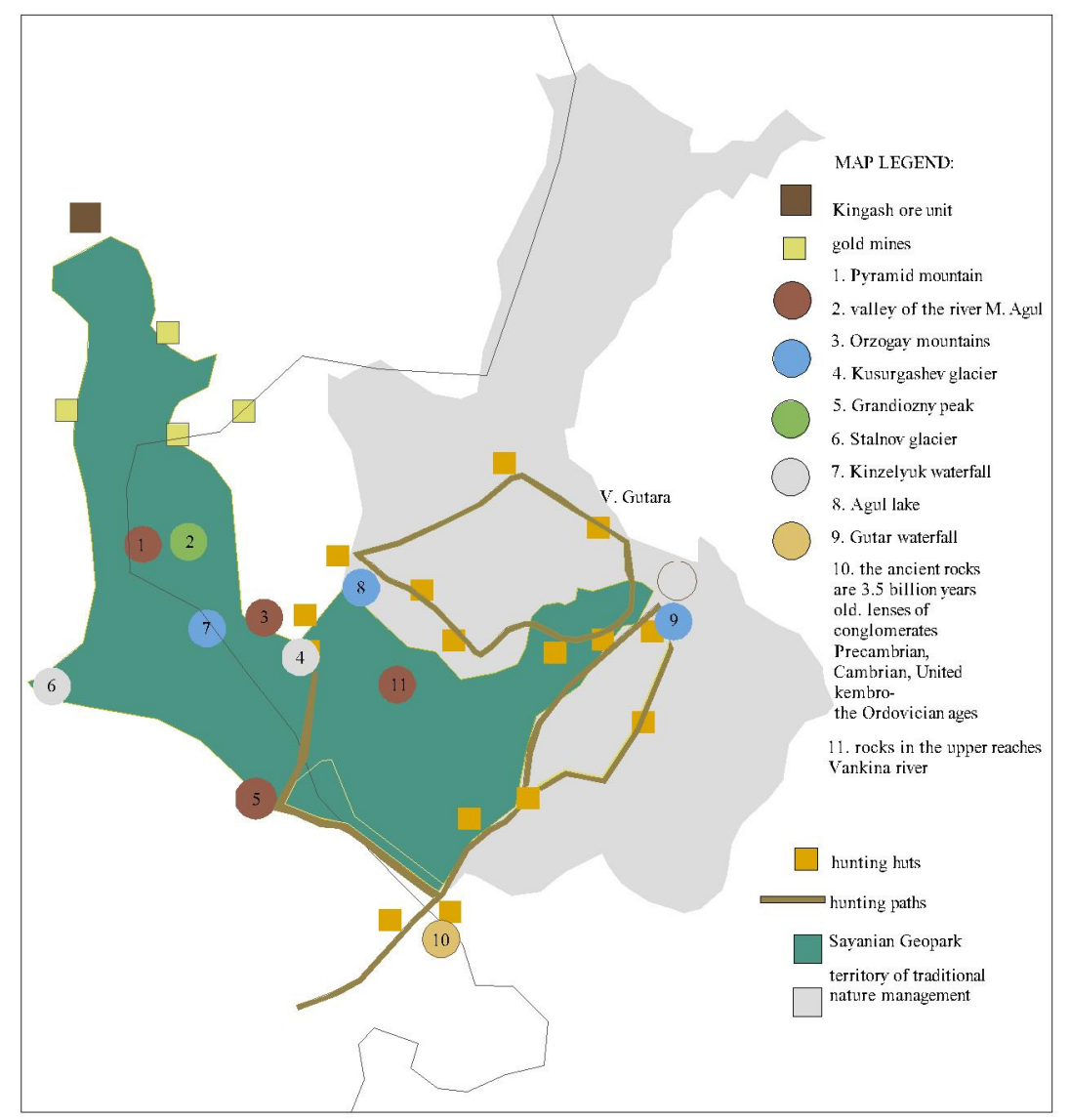

Fig. 3. Map-scheme of the Sayan Geopark and the territory of the traditional nature management

The existing and planned for opening specially protected areas in the central part of the Eastern Sayans, as well as the Sayan Geopark and the territory of traditional nature use Tofalar would restore the Sayan Reserve to the original borders as a complex of territories with different conservation status. It would be historical justice. In addition to environmental objectives, the listed specially protected natural areas fulfill the task of developing ecological tourism, the prototype of which is the established routes of amateur tourism. From the late 1950s, groups of pioneers appeared in the center of the Sayan Mountains. The first tourist group from Grandiose Peak went north to Cana. In 1957, the Moscow group under the leadership of Ju. Trinkuniss made the first tourist trip to Kizir on a wooden raft from the Kinzelyuk estuary. In 1969, in the upper reaches of the Kizir and in 1970 - the Uda, a group of Krasnoyarsk people traveled, led by A. Vavitov. And now 
amateur groups of tourists along the Agul and Gutara, Idar and Kan white mountains get to Gutarsky and Kinzelyuk waterfalls, steel glaciers and Kusurgashev, Agulsky and Medvezhy lakes, Orzagai marble mountains, Grandiose peaks and Triangulators. Thus, the development of "amateur" and sports tourism determines the significant social potential of geo-and ecotourism.

The planned highway Sayanskaya-Aginskoye-Orye-Kingash will be the contribution to improving transport accessibility of the study area.

Thus, the central part of the Eastern Sayan can be called a territory for the development of ecological tourism. In order to minimize the anthropogenic impact on the natural complexes of the Eastern Sayans, optimal functional zoning [23] of the ecotourism area is required, which corresponds to the basic principles of ecotourism, where each zone corresponds to a specific town planning regulation. The need for functional zoning occurs even in self-managed areas of ecotourism. For example, in Ecuador, in the area of the Acuari-Kopri river, for the development of tourism, areas with a network of tourist nature trails with a total length of 60 kilometers (excursions conducted by local guides), as well as strict protection zones and traditional hunting grounds (exclusively for indigenous people) were allocated. , functional zoning of tourist areas is a necessary stage in the planning of eco-tourist activities.

Analysis of frame systems [22] can serve as a methodical technique identify the ecological and recreational potential of the territory and its functional zoning. This approach allows us to predict the process of formation of recreational areas with environment-stabilizing functions.

\section{References}

1. G. Dixon, A Report to the Australian Heritage Commission, 35, 101-103 (1995)

2. W. Eder, M. Patzak, Episodes, 27 (3), 162-164 (2004)

3. M. L. Frey, G. Martini, N. Zouros, European Geoparks Magazine, 1, 28-30 (2001)

4. R. Goldring, Geological Magazine, 122 (1), 65-72 (1985)

5. T.A. Hose, Geological heritage: its conservation and management, 127-146 (2000)

6. T.A. Hose, Geology on your doorstep, 207-228 (1996)

7. T.A. Hose, Engineering geology and the environment, 2955-2960 (1997)

8. T.A. Hose, Acta geographica Slovenica, 51-3, 343-359 (2011)

9. T.A. Hose, Geoheritage, 4, 7-24 (2012)

10. S.B. Marković, D. Mijović, M. Jovanović, N. Kovačev, Protection of Nature, 53, 131138 (2001)

11. J. Pamić, Rad JAZU, 441 (23), 97-114 (1988)

12. M. Patzak, E. Eder, Geologica Balcanica, 28 (3-4), 33-35 (1998)

13. P. Pereira, D. Pereira, M. I. Caetano Alves,. Geographica Helvetica, 62 (2007)

14. M.D. Petrović, M. D. Vujicic, D. Vasiljevic, T. A. Hose, Carpathian Journal of Earth and Environmental Sciences, 8, 105-116 (2013)

15. M.E. Popa, A. Kedzior, Rev. Roum. Géologie, 53-54, 109-113 (2009)

16. J.P. Pralong, Géomorphologie. Relief, processes, environnement, 3, 189-196 (2005)

17. E. Reynard, Geografiafisica e dinamicaquaternaria, 31, 22-23 (2008)

18. Dj.A. Vasiljević, S.B. Marković, T.A. Hose., I. Smalley, B. Basarin, L. Lazić, G. Jović, Quaternary International, 240 (1-2), 108-116 (2011) 
19. W.A. Wimbledon, A. A. Ishchenko, N. P. Gerasimenko, L. O. Karis, V. Suominen, C. E. Johansson, C. Freden, Geological heritage: its conservation and management, 69-94 (2000)

20. N. Zouros, Episodes, 27 (3), 165-171 (2004)

21. N. Zouros, P. McKeever, Episodes, 28 (4), 274-278 (2005)

22. D.M. Astanin, Vestnik Moskovskogo Unviersiteta, Seriya Geografiya, 3, 51-60. (2017)

23. D.M. Astanin, Architecton. Proceedings of higher education, 63, 4, (2018)

24. G.S. Dzhamirzoev, I.A. Idrisov, Bulletin of the Dagestan State Pedagogical University. Natural and exact sciences, 11, 4, 19-27. (2017)

25. A.A. Zaitsev, Bulletin of the Samara Scientific Center of the Russian Academy of Sciences, 16, 6, 1752-1755. (2014)

26. M.K. Kalmykova, Materials of the international scientific and practical conference of students and graduate students, 64-68. (2011)

27. E.D. Korf, Science and Tourism: Interaction Strategies, 4, 5-9. (2015)

28. Yu.S. Lyakhninsky, Speleology and spelestology, 1, 308-311. (2010)

29. V.V. Makarihin, P.V. Medvedev, D.V. Rychanchik, Geological natural monuments of Karelia. Petrozavodsk. 192 p. (2006)

30. V.V. Manyuk, News of the Dnepropetrovsk Sovereign Agrarian and Economic University, 1, 87-90 (2014)

31. N.K. Nikitina, Mineral resources of Russia. Economics and Management, 2, 62-65. (2012)

32. A.A. Safaryan, A.V. Firsova, Kungursky Proceedings of the III International Scientific Seminar. Perm State National Research University. 153-159. (2014)

33. A.G. Redkin, O.V. Otto, Science and Tourism: Interaction Strategies, 4, 9-15. (2015)

34. D.A. Ruban, Bulletin of Tomsk State University, 363, 211-213. (2012) 